\title{
Migrant Consumers' Attitudes towards Homeland Products
}

\author{
Siti Z. Sahak (Corresponding author) \\ Arshad Ayub Graduate Business School, Universiti Teknologi MARA \\ 40450 Shah Alam, Malaysia \\ Tel: 60-3-554-4717Ｅ-mail: sitiza344@salam.uitm.edu.my
}

\author{
Andrew J. Newman \\ Sheffield Hallam Business School, Sheffield Hallam University \\ Sheffield S1 1WB, United Kingdom \\ E-mail: a.newman@shu.ac.uk \\ Mirella Yani-de-Soriano \\ Cardiff Business School, Cardiff University \\ Aberconway Building, Cardiff, CF10 3EU, United Kingdom \\ E-mail: yani-de-sorianoM@cardiff.ac.uk
}

Received: September11, 2014 Accepted: November 29, 2014 Published: February 1, 2015

doi:10.5296/jmr.v7i2.6955 URL: http://dx.doi.org/10.5296/jmr.v7i2.6955

\begin{abstract}
This work investigates the determinant factors of migrant consumers' willingness to buy products originate from their home country. The unit of analysis in this study was Malaysian migrants in the UK and the analysis was based on 330 usable data gathered through an online survey. The results indicate that the migrants' willingness to buy their homeland products was significantly and positively influenced by the migrants' levels of national identity. This finding suggests that the stronger the migrant consumers' association to their origin identity, the higher their willingness to purchase homeland products. The study provides a support that the migrant consumers' positive attitudes towards homeland products were not determined by the migrants' degree of ethnocentrism. The present study has implications for consumer
\end{abstract}


behavior and marketing in multicultural societies.

Keywords: Consumption, International Migration, Ethnocentrism, Identity, Assimilation 


\section{Introduction}

According to the United Nations (2014a), as at 2013, there were about 232 million of international migrants worldwide, and the number is expected to increase. Asians represented the largest diaspora group living outside of their region of birth and they accounted for about 19 million foreign-born living in Europe (United Nations, 2014b). Understanding how this migrant group functions as consumers in the host country is important to marketers in order to enhance customers' satisfaction. The central motivations of this study are to explore the migrant consumers' attitude towards products from their homeland and to examine the determinant factors to the attitude.

There are differences between immigrant and migrant, however, the term migrant is sometimes interspersed without qualification. The immigrants are found to adopt the host country for permanent residence, while the migrants are generally in a transient state. Joppke (1999: 632) best illustrates this in the context of the USA, UK and Germany by subtly referring to the relationship with citizenship policies comprising legal status and identity. The former denotes formal state membership (nationality) and the latter indicates shared understanding and practices that constitute a political community. It is this latter state of permanency (Oxford Dictionary, 2005) and interconnectivity with the host country, which is regarded as the country of settlement (Berry, Phinney, Sam \& Vedder, 2006a), that makes an immigrant so likely to assume distinctive behaviors in the context of consumption and purchasing. The migrant however views the role of the receiving country or host country quite differently (Berry et al., 2006a; Jun, Ball \& Gentry, 1993; Office for National Statistics, 2008).

The United Nations defines migrants as a collective group of people who live in countries different from the one in which they were born. This group of transient migrants, though the length of residence is temporarily in nature is still engaging in acculturation process. Acculturation refers to culture change which results from continuous, first hand contact between two distinct cultural groups (Berry, Kim, Minde \& Mok, 1987: 491). According to Douglas and Craig (1997), migration represents one of the forces that have a dramatic impact on consumer behaviour. Fundamentally, in comparison to consumers who are living in their home country, migrant consumers are constantly exposed to direct contact with a new society and culture. As established by the multi-dimensional approach of acculturation (Berry, 1980; 1997; Laroche et al., 1997; Triandis et al., 1986), this process often results in several outcomes. The migrants may begin to learn and absorb the host culture, they may maintain their original identity and culture and also, possibly, they may integrate both identities and cultures of the home country and the host country. The ways in which migrants acculturate may also bring changes to the dominant society. As Joly (2000, p. 25) articulates:

Indeed, migrants are not only objects whose moves are deterministically conditioned by structural factors, they are social actors who formulate their own strategies and life projects within given settings and conflicts in their society of origin and society of reception, which they in turn contribute to modify. 
Previous research showed that groups of different ethnic backgrounds in the UK engage in culture swapping to taste different cultures, thus rendering a traditional ethnic segmentation approach ineffective as consumers do not conform to any one specific segment (Jamal, 2003). Clearly, a deeper understanding of consumption differences within a particular subculture is essential in capitalizing on such differences (Ogden, Ogden \& Schau, 2004), and it enables international businesses operating in a multicultural marketplace to target more effectively. This paper brings together different theories and methodologies to facilitate understanding of migrant consumers' attitude towards products originated from their homeland in the context of multicultural societies.

\section{Theoretical Foundations and Hypotheses}

\subsection{Consumer Ethnocentrism}

In the field of marketing, existing studies in consumer behavior have addressed consumer ethnocentrism as a factor which underlies consumer favoritism towards home country products (Balabanis \& Diamantopoulos, 2004; Papadopoulos \& Heslop, 1993; Samiee, 1994; Shimp \& Sharma, 1987). Highly ethnocentric consumers tend to exhibit a positive attitude towards home country products, while low ethnocentric consumers are likely to evaluate the products based on their attributes rather than their origins (Shimp \& Sharma, 1987). Indeed, work in this area is evident from the study of consumer ethnocentrism within and across nations (De Mooij, 2000; Laroche, 2007; Yaprak, 2008).

Past studies show that $\mathrm{CE}$ is a significant factor in influencing consumer willingness to buy home country products. Highly ethnocentric consumers tend to exhibit this positive bias either by evaluating domestic products positively (Shimp and Sharma, 1987; Samiee, 1994) or by indicating a willingness to purchase domestic products (Watson and Wright, 2000; Wang and Chen, 2004). To our best knowledge no work has been carried out to examine the relationship between $\mathrm{CE}$ and willingness to buy in the context of migrant consumers. However, prior work by Sharma, Shimp and Shin (1995) has shown that when individuals have opportunities to expose themselves to the culture of other groups, the bias towards "out-groups" is lessened. Their study also found the degree of cultural openness to be inversely correlated to consumer ethnocentrism. This is underpinned by Douglas and Nijssen's (2003) later work which stresses that consumers who are keen on travelling abroad tend to exhibit favorable attitude towards foreign products. Thus, it is hypothesized that:

H1: Consumer ethnocentrism will inversely influence migrant consumers' willingness to buy their home country products

\subsection{Acculturation}

There are two major streams of acculturation theory (Cleveland \& Laroche, 2007), the uni-dimensional approach and the multi-dimensional approach. The uni-dimensional is often referred to as assimilation theory. According to Gordon (1964) when people are immersed in a new and different culture they progressively learn about other cultures, and lose either part or the entire heritage of their origins. Multi-dimensional or bidirectional approaches suggest that assimilation is not the only outcome of the acculturation process. Adjustment of the 
acculturating individual may result in different forms of coping strategies (Berry, 1980, 1997; Laroche, Kim, Hui \& Tomiuk, 1997; Triandis, Kashima, Shimada \& Villareal, 1986) leading to various outcomes. Berry identifies four modes of acculturation: assimilation, separation, integration and marginalization. They are underpinned by two dimensions: one's concern for one's original culture and identity ("in-group"), and the added concern for maintaining a relationship with the new culture ("out-group"). In contrast to separation, assimilation indicates migrant's preference towards "out-group", as individuals do not wish to maintain their cultural identity and seek daily interaction with other cultures (Berry, 1997: 9). Hence, the hypothesis is:

H2: Assimilation will inversely correlate to migrant consumers' willingness to buy products originated from their home country.

\subsection{National Identity}

The term 'cultural identity' is commonly referred to as how individuals associate themselves with their original culture and the new culture (Berry et al., 2006a). In the context of acculturation, cultural identity is often divided into two: host country identity (new culture) and ethnic identity (original culture). However, there is an argument that 'there is no single ethnic identity' exists. Oswald (1999: 304) claims that 'ethnicity can be bought, sold, and worn like a loose garment'. In cross-cultural studies, Keillor, D’Amico and Horton (2001) found out that the Malaysian sample (aged 15 to 55 and over) recorded significantly higher level of national identity than the US sample. This self-identification is likely to be translated to a positive attitude towards home country products. The prediction is:

H3: National identity will significantly influence migrant consumer s' willingness to buy home country products

The theoretical framework in Figure 1 illustrates all the relevant constructs and their hypothesized relationships.

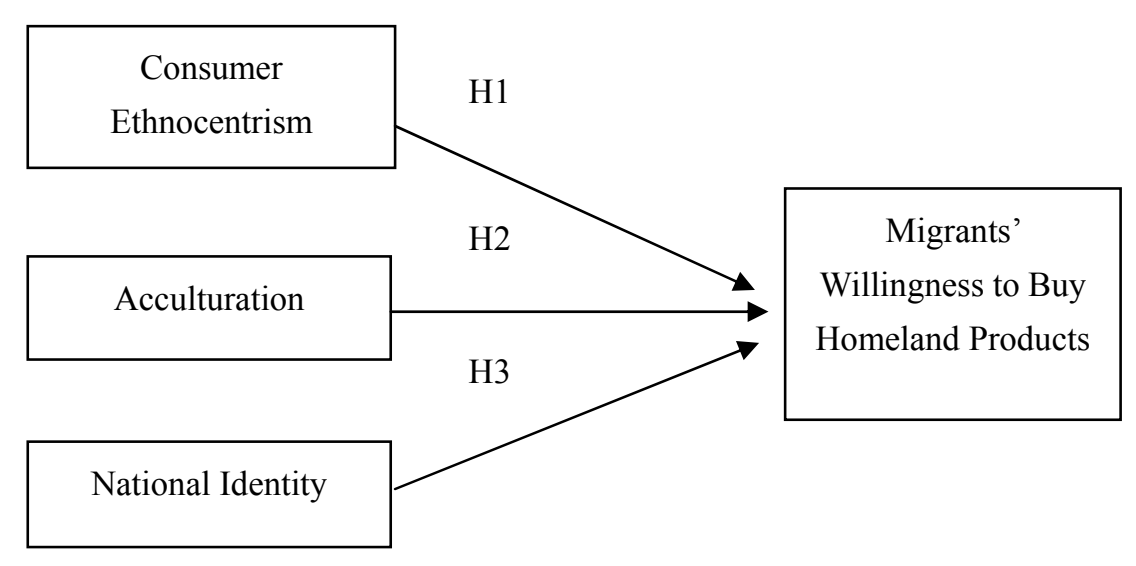

Figure 1. Theoretical Framework 


\section{Methodology}

\subsection{Research Design}

The target population for this study is Malaysian migrants in the UK. As at 2013, they represent the second largest group of South-East Asian migrants residing in the country (Office for National Statistics, 2014). Study showed that most Malaysians come to the UK for furthering their studies and/or working purposes rather than for settling down permanently (International Organization for Migration, 2009). Based on the nature of migration of the target populations, the samples were divided into two namely, students and non-students. A posted web-link of the questionnaire was employed for accessing these two broad cross-sectional Malaysian migrants through the Malaysian community associations throughout the UK. 384 responses were obtained and upon screening 330 were included in the analysis. 54 responses were excluded from the analysis due to incomplete data as recorded in the web-survey software.

\subsection{Measures}

The study measures include consumer ethnocentrism, acculturation, national identity and willingness to buy home country products and demographics. All the scales employed are well established in the literature. The degree of consumer ethnocentrism was measured using an established scale, 'Consumer Ethnocentrism Tendency Scale' (CETSCALE) (Shimp \& Sharma, 1987). A shortened version of CETSCALE, which consists of 10 items measured on a five-point Likert scale ( 1 = "strongly disagree" to $5=$ "strongly agree") was used in this study (Balabanis \& Diamantopoulos, 2004; Netemeyer et al., 1991; Steenkamp \& Baumgartner, 1998). Three modes of acculturation: assimilation, integration and separation (Berry, 1980; Penaloza, 1989) were measured by 12 items (Berry, Phinney, Sam \& Vedder, 2006b), also rated on a five-point Likert scale. National identity was measured by six items adapted from Phinney (1992) and Phinney and Devich-Navarro (1997). The scale for 'willingness to buy home country products' was adapted from Klein et al. (1998) which consists of five items, also measured on a five-point Likert scale. Finally, demographics included the following variables: gender, age, education level, occupation, marital status and length of residence in the UK.

\section{Analysis and Result}

The demographic profile shows that the respondents were predominantly from young and middle aged groups (18 to 39 years old). The majority of respondents live in the UK with an average length of residence of 3 years. In total, $78 \%$ of the respondents were university students, $8 \%$ were the students' dependant and the remaining $14 \%$ were non-students. On the average, the respondents had been in the UK for 2 years and 9 months.

Exploratory factor analysis was conducted (principal components with Varimax rotation) to uncover the dimensionality and the underlying structure of the constructs. The number of factors retained was guided by Eigen value greater than 1 and the scree plot (Hair, Black, Babin, Anderson \& Tatham, 2006; Pallant, 2007). Due to either low loading or cross-loading the following items were dropped CET2, CET8, ICUL, W2B3 and W2B5. Items retained 
based on the exploratory factor analysis results were then subjected to further analysis using AMOS 17. The model fit was assessed and then modified by pruning the items with loadings of 0.50 and below, and items with residual values of 2.5 and above (Hair et al., 2006). In all, four items were dropped CET3, ALANG, SLANG and RISOC. The resultant measurement models produced an adequate fit $\left(\chi^{2}=269.21, \mathrm{df}=125, \quad \mathrm{p}=0.000, \quad \mathrm{RMR}=\right.$ $0.03, \mathrm{GFI}=0.92, \mathrm{TLI}=0.92, \mathrm{CFI}=0.94, \quad \mathrm{RMSEA}=0.06)$.

The next stage considered the reliability and average variance explained (AVE) for all constructs in the model. This produced composite reliability (CR) and Cronbach's alpha ( $\boldsymbol{\alpha})$ scores respectively for the consumer ethnocentrism scale of 0.89 each. For acculturation mode, the separation items, achieved AVE and alpha coefficients of 0.35 and 0.50 respectively which is far below the recommended values. Hence, acculturation is represented by the items of assimilation only and those items measuring separation were dropped from further analysis. The key results for the measurement model are summarized in Table 1, highlighting the inter-construct correlation and the squared correlations, which were all within the recommended cut-off points (see Kline, 2005; Hair et al., 2006). This provides support for the convergent and discriminant validity of the constructs.

Table 1. Descriptive statistics and inter-construct correlations

\begin{tabular}{|c|c|c|c|c|c|c|}
\hline Constructs & 1 & 2 & 3 & 4 & Mean & $\mathrm{SD}$ \\
\hline $\begin{array}{l}\text { 1.National } \\
\text { identity }\end{array}$ & & -0.05 & 0.03 & 0.20 & 4.4 & 0.53 \\
\hline 2. Assimilation & $-0.23 * * *$ & & 0.03 & -0.17 & 1.7 & 0.56 \\
\hline $\begin{array}{l}\text { 3.Consumer } \\
\text { ethnocentrism }\end{array}$ & $0.17 * * *$ & $0.17 * * *$ & & -0.02 & 2.2 & 0.78 \\
\hline $\begin{array}{l}\text { 4. Willingness to } \\
\text { buy Malaysian } \\
\text { products }\end{array}$ & $0.45^{* * *}$ & $-0.42 * * *$ & $-0.15 * * *$ & & 4.4 & 0.58 \\
\hline
\end{tabular}

Notes: $* * * \mathrm{p}<0.001 ;$ figure in bold represents the squared correlation between constructs

The measurement model was then converted to a structural model to test the hypothesized relationships between consumer ethnocentrism, assimilation, national identity and willingness to buy Malaysian products. The results of the model fit indices suggest conformance of the model to the data $\left(\chi^{2}=236.72, \mathrm{df}=87, \mathrm{GFI}=0.92, \mathrm{RMSEA}=0.07, \mathrm{CFI}=0.93\right.$ and $\mathrm{TLI}=$ 0.91). 
The results for Hypotheses 1, 2 and 3 are presented in Table 2. The result indicates significant negative correlation between consumer ethnocentrism and willingness to buy home country products. Thus, this provides a support for Hypothesis 1. Hypothesis 2 is also supported as the analysis showed that assimilation has a negative impact on migrants' willingness to buy home country products. This indicates the more assimilate the migrants are, the lower their willingness to buy products originated from their homeland. As expected, national identity significantly influenced the respondents' willingness to buy home country products, providing evidence for Hypotheses 3.

Table 2. Hypotheses testing and results

\begin{tabular}{llllll}
\hline & Antecedents & Criterion variable & Estimate & $t$-value & Result \\
\hline H1 & $\begin{array}{l}\text { Consumer } \\
\text { ethnocentrism }\end{array}$ & Willingness to buy & -0.18 & $-2.97^{* *}$ & Supported \\
H2 & Assimilation & Willingness to buy & -0.32 & $-4.37 * * *$ & Supported \\
H3 & National identity & Willingness to buy & 0.43 & $5.90^{* * *}$ & Supported \\
Notes: & $* * * \mathrm{p}<0.001$ & $* * \mathrm{p}<0.01$ & & \\
\hline
\end{tabular}

\section{Discussion and Conclusions}

The key contribution from this study is that, for the first time, it recognizes a different and new type of transient consumer: the migrant. The theoretical and practical implications arise from uncovering the distinctive consumption behavior of migrants and establishing a relationship among consumer ethnocentrism, acculturation, national identity and migrants' willingness to buy homeland products. The main insights gained from this research come from the unique glimpse of a highly collective and culturally-knit set of consumers living outside their country for a reduced period. Conceptually and intuitively migrants would seem to be set apart from other residents by the limitations above, and how these factors influence their state of mind vis-à-vis consumption. Hence, these consumers differ widely from immigrants, yet this distinction seems to be absent from the consumer behavior literature.

This new conceptualization builds on and extends beyond previous research which suggested that individuals exposed to other cultures are less biased towards "out-groups" (Sharma et al., 1995), and tend to have a more positive attitude towards foreign products (Douglas \& Nijssen, 2003). The negative relationship between consumer ethnocentrism and willingness to buy home country products contradicts previous research taken place within consumers' national border, which found that ethnocentrism is more relevant in explaining consumers' positive bias towards own country products than negative bias towards foreign products (Balabanis \& Diamantopoulos, 2004; Shimp \& Sharma, 1987).

Of significant, our results strongly support previous claims which state that consumers with high level of national identity reflects their willingness to buy home country products (Verlegh, 2007). In fact, products often serve as a symbol for national identity due to their social and cultural meanings, and consumers express this identity through their choice of products (Askegaard \& Ger, 1998). The findings suggest that given the transient state, which is a delimiting characteristic of migrants, and although the present sample of migrants 
acknowledge the need to acclimatize, they feel more strongly about their cultural identity as their host country is never likely to be their permanent place of residence. This insight has the potential to transform the way international marketers treat customer bases.

In sum, this present study documents that Malaysian migrants' willingness to buy Malaysian made products while residing in the UK is strongly influenced by their sense of national identity as Malaysians. Consumer ethnocentrism and assimilation were found to inversely effect their attitudes towards the homeland products. The fact that migrant consumption alters with acculturation over time, however short, makes the task of examining behaviors very demanding for a number of reasons. Firstly, migrant consumers likely assign different values to products and services than, for example, immigrants who are more likely to immerse themselves in the new culture (Lee \& Tse, 1994). Clearly the importance placed on consumables will vary with levels of involvement (low/high) within categories such as necessity versus luxury and geographical pricing levels. There are of course a plethora of ethnocentrism studies showing differing behavior across product categories (Balabanis \& Diamantopoulos, 2004: Sharma et al., 1995), and in the context of local or cross-national purchasing. The study reported here demonstrates that it is equally important to define how a migrant consumer's society of origin and purpose of migration influences behavior.

\section{References}

Askegaard, S., \& Ger, G. (1998). Product-country images: toward a contextualized approach. European Advances in Consumer Research, 3(1), 50-58.

Balabanis, G., \& Diamantopoulos, A. (2004). Domestic country bias, country- of-origin effects and consumer ethnocentrism: A multidimensional unfolding approach. Journal of the Academy of Marketing Science, 32(1), 80-95. http://dx.doi.org/10.1177/0092070303257644

Berry, J. W. (1980). Acculturation as adaptation. In A. M. Padilla (Ed.), Acculturation: Theory, models, and some new findings: 9-26.Boulder: Westview Press.

Berry, J. W. (1997). Immigration, acculturation and adaptation. Applied Psychology: An International Review, 46(1), 5-68. http://dx.doi.org/10.2307/2546607

Berry, J. W., Kim, U., Minde, T., \& Mok, D. (1987). Comparative studies of acculturative stress. International Migration Review, 21(3), 491-511.

Berry, J. W., Phinney, J. S., Sam, D. L, \& Vedder, P. (2006a). Immigrant youth: Acculturation, identity and adaptation. Applied Psychology: An International Review, 55(3), 303-332. http://dx.doi.org/10.1111/j.1464-0597.2006.00256.x

Berry, J. W., Phinney, J. S., Sam, D. L., \& Vedder, P. (Eds.). (2006b). Immigrant youth in cultural transition: Acculturation, identity and adaptation across national contexts. London: Lawrence Erlbaum Associates.

Cleveland, M., \& Laroche, M. (2007). Acculturation to the global consumer culture: Scale development and research paradigm. Journal of Business Research, 60(3), 249-259. http://dx.doi.org/10.1016/j.jbusres.2006.11.006 
De Mooij, M. (2000). The future is predictable for international marketers: Converging incomes lead to diverging consumer behavior. International Marketing Review, 17(2), 103-113. http://dx.doi.org/10.1108/02651330010322598

Douglas, S. P., \& Craig, C. S. (1997). The changing dynamic of consumer behavior: Implications for cross-cultural research. International Journal of Research in Marketing, 14, 379-395. http://dx.doi.org/10.1016/S0167-8116(97)00026-8

Douglas, S. P., \& Nijssen, E. J. (2003). On the use of "borrowed" scales in cross-national research: A cautionary note. International Marketing Review, 20(6), 621-642. http://dx.doi.org/10.1108/02651330310505222

Gordon, M. M. (1964). Assimilation in American life: The role of race, religion and national origins. New York: Oxford University Press.

Hair, J. F. Jr., Black, W. C., Babin, B. J., Anderson, R. E., \& Tatham, R. L. (2006). Multivariate data analysis (6th. ed.). New Jersey: Pearson-Prentice Hall.

International Organisation for Migration United Kingdom. (2009). Mapping exercise: Malaysia. http://www.iomlondon.org [accessed on 1 April 2009].

Jamal, A. (2003).Marketing in a multicultural world: The interplay of marketing, ethnicity and consumption. European Journal of Marketing, 37(11/12), 1599-1620. http://dx.doi.org/10.1108/03090560310495375

Joly, D. (2000). Some structural effects of migration on receiving and sending countries, International Migration, 38(5), 25-40. http://dx.doi.org/10.1111/1468-2435.00126

Joppke, C. (1999). How immigration is changing citizenship: a comparative view. Ethnic and Racial Studies, 22(4), 629-652. http://dx.doi.org/10.1080/014198799329323

Jun, S., Ball, A. D., \& Gentry, J. W. (1993). Modes of consumer acculturation. Advances in Consumer Research, 20(1), 76-82.

Keillor, B. D., D’Amico, M. \& Horton, V. (2001). Global consumer tendencies. Psychology \& $\quad$ Marketing, $\quad 18(1), \quad 1-19$. http://dx.doi.org/10.1002/1520-6793(200101)18:1<1::AID-MAR1>3.0.CO;2-U

Klein, J. G., Ettenson, R., \& Morris, M. D. (1998). The animosity model of foreign product purchase: An empirical test in the People's Republic of China. Journal of Marketing, 62(1), 89-100. http://dx.doi.org/10.2307/1251805

Kline, R. B. (2005). Principles and practice of structural equation modeling (2nd. ed.). New York: Guilford Press.

Laroche, M. (2007). Editorial: Introduction to the special issue on the impact of culture on marketing strategy. Journal of Business Research, 60(3), 177-180. http://dx.doi.org/10.1016/j.jbusres.2006.11.001

Laroche, M., Kim, C., Hui, M., \& Tomiuk, M. (1997). A multidimensional perspective on 
acculturation and its relative impact on consumption of convenience foods. Journal of International Consumer Marketing, 10(1/2), 33-56.

Lee, W., \& Tse, D. K. (1994). Becoming Canadian: Understanding how Hong Kong immigrants change their consumption. Pacific Affairs, 67(1), 70-95. http://dx.doi.org/10.2307/2760120

Netemeyer, R. G., Durvasula, S., \& Lichtenstein, D. R. (1991). A cross-national assessment of the reliability and validity. Journal of Marketing Research, 28(3), 320-327. http://dx.doi.org/10.2307/3172867

Office for National Statistics. (2014). Population trends. Population by Country of Birth and Nationality Report, http://www.ons.gov.uk/ons/dcp171776 375449.pdf [accessed on 21 November 2014].

Ogden, D. T., Ogden, J. R, \& Schau, H. J. (2004). Exploring the impact of culture and acculturation on consumer purchase decisions: Toward a microcultural perspective. Academy of Marketing Science Review, 3, 1-22.

Oswald, L. R. (1999). Culture swapping: Consumption and the ethnogenesis of middle-class Haitian immigrants. Journal of Consumer Research, 25(4), 303-318. http://dx.doi.org/10.1086/209541

Pallant, J. (2007). SPSS survival manual. England: McGraw Hill.

Papadopoulos, N., \& Heslop, L. A. (1993). Product-country images: Impact and role in international marketing. New York: The Haworth Press.

Penaloza, L. (1989). Immigrant consumer acculturation. Advances in Consumer Research, 16, $110-118$.

Phinney, J. (1992). The Multi-group ethnic identity measure: A new scale for use with diverse groups. Journal of Adolescent Research, 7(2), 156-176. http://dx.doi.org/10.1177/074355489272003

Phinney, J., \& Devich-Navarro, M. (1997). Variations in bicultural identification among African American and Mexican American adolescents. Journal of Research on Adolescence, 7(1), 3-32. http://dx.doi.org/10.1207/s15327795jra0701_2

Samiee, S. (1994). Customer evaluation of products in a global market. Journal of International Business Studies, 25(3), 579-604. http://dx.doi.org/10.1057/palgrave.jibs. 8490213

Sharma, S., Shimp, T. A., \& Shin, J. (1995). Consumer ethnocentrism: A test of antecedents and moderators. Academy of Marketing Science Journal, 23(1), 26-37. http://dx.doi.org/10.1007/BF02894609

Shimp, T. A., \& Sharma, S. (1987). Consumer ethnocentrism: Construction and validation of the CETSCALE. Journal of Marketing Research, 24(3), 280-289. http://dx.doi.org/10.2307/3151638 
Steenkamp, J. E. M. \& Baumgartner, H. (1998). Assessing measurement invariance in cross national consumer research. Journal of Consumer Research, 25(1), 78-107. http://dx.doi.org/10.1086/209528

Triandis, H.C., Kashima, Y., Shimada, E., \& Villareal, M. (1986). Acculturation indices as a means of confirming cultural differences. International Journal of Psychology, 21(1), 43-70. http://dx.doi.org/10.1080/00207598608247575

United Nations. (2009). International Migration Report 2006: A global assessment. http://www.un.org/esa/population/publications/2006_MigrationRep/report.html [accessed 22 September 2010].

United Nations. (2014a). Report of the Secretary - General on International Migration and Development. Department of Economic and Social Affairs, Population Division. Department of Economic and Social Affairs, Population Division. http://www.un.org/en/development/esa/population/migration/documents/Report_of_the Secretary_General_on_International_Migration_and_Developmen.pdf [accessed on 21 November 2014]

United Nations. (2014b). International Migration 2013: Migrants by Origin and Destination, No. 2013/3 Rev. 1, Department of Economic and Social Affairs, Population Division. Department of Economic and Social Affairs, Population Division. http://www.un.org/en/development/esa/population/publications/pdf/popfacts_2013-3Rev1_ne w.pdf [accessed on 21 November 2014]

Verlegh, P. W. J. (2007). Home country bias in product evaluation: the complementary roles of economic and socio-psychological motives, Journal of International Business Studies, 38(3), 361-373. http://dx.doi.org/10.1057/palgrave.jibs.8400269

Wang, C. L., \& Chen, Z. X. (2004). Consumer ethnocentrism and willingness to buy domestic products in a developing country setting: testing moderating affects. Journal of Consumer Marketing, 21(6), 391-400. http://dx.doi.org/10.1108/07363760410558663

Watson, J. J., \& Wright, K. (2000). Consumer ethnocentrism and attitudes toward domestic and foreign products. European Journal of Marketing, 34(9/10), 1149-1166. http://dx.doi.org/10.1108/03090560010342520

Yaprak, A. (2008). Culture study in international marketing: A critical review and suggestions for future research. International Marketing Review, 25(2), 215-229. http://dx.doi.org/10.1108/02651330810866290

Lawrence, S. et al. (2001). Persistence of Web References in Scientific Research. Computer, 34, 26-31. http://dx.doi.org/10.1109/2.901164

Smith, Joe. (1999). One of Volvo's core values. [Online] Available: http://www.volvo.com/environment/index.htm (July 7, 2007)

Strunk, W., Jr., \& White, E. B. (1979). The elements of style (3rd ed.). New York: Macmillan, (Chapter 4). 


\section{Macrothink}

Journal of Management Research

ISSN 1941-899X

2015, Vol. 7, No. 2

Van der Geer, J., Hanraads, J. A. J., \& Lupton R. A. (2000). The art of writing a scientific article. Journal of Scientific Communications, 163, 51-59

\section{Copyright Disclaimer}

Copyright for this article is retained by the author(s), with first publication rights granted to the journal.

This is an open-access article distributed under the terms and conditions of the Creative Commons Attribution license (http://creativecommons.org/licenses/by/3.0/). 